\title{
Manufacturing Authenticity: The Rise of Indonesian Micro-Celebrities on Instagram
}

\author{
Aulia Rahmawati \\ ORCID iD: 0000-0003-4250-7443, Universitas Pembangunan Nasional "Veteran" Jawa \\ Timur, Jl. Raya Rungkut Madya, Gunung Anyar, Surabaya, East Java 60294, Indonesia \\ *Corresponding author, e-mail: aulia_rahmawati.ilkom@upnjatim.ac.id
}

\begin{abstract}
This paper interrogates the way in which Instagram, as one of the most famous microblogging participatory online media in the world, creates the production, consumption and articulation of the so-called micro-celebrity. The concept of micro-celebrity has been expanded to unearth the phenomenon of someone who has gained massive online popularity and followers based on their online-persona. Despite its burgeoning prominence, there is a lacuna of research addressing the emergence of micro-celebrities in Indonesia and the way in which Instagram facilitates such trajectories. This paper focuses on Instagram and how this platform helps to build celebrity online persona by examining what and how discourses have been embodied and reproduced by local (Indonesia) micro-celebrities. Using multimodal discourse analysis, this paper concludes that both discourses of authenticity and ordinariness are mostly prevailing in both Dian Pelangi and Arief Muhammad's Instagram accounts. Dian Pelangi and Arief Muhammad's rise to fame through online platform such as Instagram confirmed the digital myth that the Internet is the place of meritocracy where everyone can thrive without acknowledging the structural inequality toward those who lack in access or knowledge in achieving the same level of success.
\end{abstract}

Keywords: Micro-Celebrity, Authenticity, Ordinary, Instagram, Multimodal Discourse Analysis.

\section{Introduction}

With the array of social media platforms, the ways in which celebrities channel their popularities are vastly expanded. Not only social media has become the extension of traditional celebrities, a 'new breed' of social media celebrities are emerged (Haastrup, 2020; Zulli, 2017). Traditional celebrities are easily identified by their talents; however, on the other hand, social media celebrities offer various distinctions, apart from their talents (Chung \& Cho, 2014; Khamis et al., 2016; Lee \& Kim, 2020). Whereas social media and celebrities have been investigated, Indonesian social media celebrities are still under-researched. Thus, this paper sought to fill this gap. This paper investigates the Instagram's micro-celebrities phenomenon in an Indonesian context. The term microcelebrities is used in this paper to define those who are not a 'real' celebrities in a sense that they are not gaining prominence following the mainstream entertainment industry, but used their online platforms to catapult their stardom as well as capitalize their fame. Hence, this paper seeks to interrogate the way in which Indonesian micro-celebrities such Dian Pelangi and Arief Muhammad managed their online-personae to gain massive online popularity. Utilizing multimodal discourse analysis along with closely monitoring the dynamic interaction with their followers, this paper addresses the following research trajectories: what kind of discourses are prevalent in Dian Pelangi and Arief Muhammad's accounts and how does Instagram facilitate such discourses?

Meanwhile, Instagram is the biggest digital participatory micro-blogging platform in the world, where written text and images along with the dynamic interplay within the

Article History: Received October 31, 2019; Revised June 16, 2020; Accepted January 03, 2021; Published November 04, 2021 
account users and their followers are allowed to take place in real time. Within the realms of online participatory dynamics, there exists the so-called micro-celebrities, the term used to describe someone who has gained prominence based on their online performance and the marketization of self-presentation (Senft, 2008). In recent years, Instagram seemingly paved the new 'breed' of celebrities, micro-celebrities, those who gained prominence without 'traditional' definition of talents (Khamis et al., 2016). This paper focuses upon the way in which Instagram facilitates such phenomenon.

The development and rapid expansion of social networking sites (which are more popular with catchphrase social media) enabled people not only to interact and communicate with each other in real time but also blur the distance between famous people and their fans. While mainstream media is usually seen as distanced and mediated, social media brings benefit to cut these distance. Numerous researches have been done to investigate the role social media has in mediating famous people and their fans (Djafarova \& Trofimenko, 2018; Giles, 2002; Hall-Patton, 2014).

On the other hand, social media has also become a new platform to fame discoveries through the lens of ordinary people. Theresa Senft, in her pivotal research around the popularity of cam girls, signified the shift of celebrity culture, when one does not need to have an appeal and extraordinary talent to carve popularity in the traditional sense of the entertainment industry (i.e.: singing or acting), but to have an ability to communicate and engage with the online audience. Senft focused her research upon the emerging of cam girls, predominantly young, white and middle-class females who set up their web-cams and talked to their audiences on a daily basis about the most mundane activities. Based on her ethnographic research, she then coined the term micro-celebrity which can be defined as, a new online performance in which people employ webcams, video, audio, blogs and social networking sites to 'amp up' their popularity among readers, viewers, and those to whom they are linked online (Senft, 2008).

Furthermore, Senft extends her research on how social network in a sense democratizes the way celebrity is made and measured. Celebrities are no longer defined by their extraordinary talents through mediated consumption of traditional mass media like films, television and magazines, but rather based on their ability to transcend emphatic communication skills and transform their ordinariness into being somewhat appealing to their online fans and followers (Evans et al., 2017; Fitrianti et al., 2020; Francis et al., 2018; Jerslev, 2019; Senft, 2008).

The likeability of 'ordinary people' is also the reality television formulaic narratives (Borges-Rey, 2015; Burke \& Ruppel, 2014; Choi \& Lewallen, 2017). As has been argued elsewhere, reality television has a similar narrative which revolves around personal triumph over ordinary obstacle (Biressi \& Nunn, 2008b). The Kardashian families, for example, amped up their super stardom from the basis of their no-apparent talents, other than capitalizing personal and sometimes domestic narratives and family dramas into reality television. Such narrative of ordinary women doing ordinary things is also strongly emerged in ethnographic research on Muslim women bloggers (Rahmawati, 2019; Rahmawati \& Febriyanti, 2012). Not only attracted to the glamour of the lives of Muslim fashion bloggers, blogs' readers also seemingly love the aspect of ordinary lives from their favorite fashion bloggers, such as pregnancy and motherhood and all that is related to domestic spheres of ordinary citizens (Rahmawati, 2009).

Instagram is one of the biggest micro-blogging and photo sharing platforms, where one controls and produces their own self-personae and where social and economy capital 
is gained through how many times one picture gains 'attention'. It is suggested that, since being sold to Facebook in 2014, Instagram has 150 million active users with 55 million photographs posted each day and 1.2 billion likes each day. Specifically focusing upon Instagram, numerous research has been done on the way in which Instagram makes its way of transforming the lives of ordinary people into fame by capitalization of online followers (Djafarova \& Trofimenko, 2018; Giles, 2002; Hall, 1999; Khamis et al., 2016). Research on young female Instagram users in Russia suggested that micro-celebrities' credibility can be measured by text and interesting visual images (Djafarova \& Trofimenko, 2018). They also used the term 'instafamous' to signify the emergent trend of Instagram celebrities to differentiate them from celebrities in a more traditional sense.

Such assertion is exemplified in the relation of micro-celebrities and self-branding, a concept that has been around for the last 20 years following the globalization process. They argued that the marketization of the self, or the late capitalism logic that everybody should perceive themselves as brands is being intensified by the expansion of online participatory culture (Khamis et al., 2016). Social media or social networks like Facebook, Twitter and Instagram ought to be seen as a global marketplace where self could be marketed as commodity. Furthermore, they argue that the success formula for micro-celebrities usually revolves around a promise of authenticity (Franssen, 2019; Ingleton \& York, 2019; Kalika \& Ferrucci, 2019; Kaymas \& Yakin, 2019; Marshall et al., 2015; Mohamad \& Hassim, 2019).

The promise of authenticity is achieved by the exposure of the true self and crafted identity through online conversation (Marshall et al., 2015). Based on Senft's study, cam girls often talked to their fans as confessional online diaries about their daily mundane lives including eating disorders and stress-related problems. The willingness to open up to their followers about the upside down of human lives somewhat makes ordinary people gain prominence as micro-celebrities. This is also the online strategy that is often exemplified by the so-called lifestyle bloggers, who often take their fans and followers to bear witness to a glimpse of their lives and transcend such level of closeness and intimacy that surely could not be achieved by more traditional media (Berryman \& Kavka, 2017; Octaviana, 2016; Pan \& Zeng, 2017; Rahmawati, 2018).

It is also worth noting that the 'traditional' celebrities also follow the social media path, since mainstream media is no longer viable as a sole medium for celebrities' popularities management (MacIsaac et al., 2017; Marshall, 2010; Marshall et al., 2015). Fans are no longer satisfied looking at their celebrity darlings only from magazines or other periodicals solely. Similar research on traditional celebrities who embraced social media to reach to wider audience signified the importance of embracing social media for the already established artist, such as Lady Gaga (Click et al., 2013). With 29.3 million Instagram followers who famously identified themselves as 'little monsters', Lady Gaga not only established herself as the cultural icon of global popular music but also amplified her message around the importance of self-acceptance and respect for others, including her campaign against school bullying and homophobia. Social media, in this sense, not only paves the way of ordinary people to gain instant fame, but also to navigate and serve as a popularity booster for already famous celebrities. Such democratization of fandom makes way for a more complex and ambivalent relationship between celebrities and their fans and thus it is imperative for more nuanced definition of what it means to be celebrity and their fans in the digital world (Giles, 2017). 


\section{Methods}

Dian Pelangi and Arief Muhammad are chosen as the perfect example of microcelebrities phenomenon. Dian Pelangi started her 'online' presence from her personal blogs while also being one of the most prominent of Indonesian Muslim designers and the founder of Hijabers Community. Hitherto, her Instagram has 5.1 million followers who bear witness to her rites of passage from single, to marriage, to divorced, remarried and motherhood. While Dian Pelangi has been clear promoting her true identity from the very beginning, Arief Muhammad had an interesting start. His online presence was started from being a widely popular and hilarious anonymous Twitter account (@Poconggg). It took several years for him to reveal his true identity before using YouTube and Instagram as his main platforms. Arief Muhammad has 4.8 million Instagram followers while also managing his content creator business through YouTube and other business endeavors such as culinary (cakekekinian and miebangcad). Muhammad's followers also bear witness to his rites of passage from college student, bachelor and now, a newlywed.

This research employs multimodal discourse analysis, to look at how two local (Indonesian) micro-celebrities constructed their self-personae through their Instagram accounts and the commentaries from their followers over certain posts. Two celebrities who are very popular in Indonesia were chosen as the object of this research, they are Dian Pelangi (IG: dianpelangi) and Arief Muhammad (IG: ariefmuh). Those two are amongst Indonesian selebgram (Instagram celebrities) that have gained over 4 million followers and always make the ten most popular Indonesian Instagram celebrity lists. Those two also gained prominent solely because of their online media presence, and not through more traditional pathways in the entertainment industry. Multimodal discourse analysis, derived from semiological and discourse tradition especially the ones developed by Michael Halliday, intends to look at the relation between language, text and context within the popular culture spheres. For years, scholars in media and cultural studies interrogated how the combination of pictures, sounds, images and text make meaning (Machin \& Mayr, 2012). Furthermore, such study also looked at how language plays an important part in the meaning-making process and thus a sign system derived from the combination of visual, text, sounds being treated as the more complex and nuanced system (Caldeira, 2020; Ghaffari, 2020; Lee \& Kim, 2020; Rahmawati \& Febriyanti, 2012). Multimodal discourse analysis offers a more systematic tool to interrogate the way media texts, in this case Instagram texts, conveyed meaning and constructed the discourse system (Machin \& Mayr, 2012). Multimodal discourse analysis has been profoundly used not only in traditional media text, but also in the digital media texts, such as government websites (Lau, 2010).

\section{Results}

The last section indicated that the two Instagram accounts of Dian Pelangi and Arief Muhammad are chosen as visual texts for the purpose of this research. The decision upon the choice was based on that both names have been considered as among the first generation of Instagram celebrities or influencers with millions of followers across multimedia platforms. Pictures are selected from their IG feed based on the similarity, newness and relevance to the objective of this research.

The first picture was taken from Dian Pelangi's Instagram post on August 17, 2020, by which she documented picture and video collages from the birth of Rumi (her first child). Celebrating her daughter's birthday, Pelangi combined the visual image and videos 
in aesthetically signifying the big 'living moments' of the precious birth of her daughter. One post was taken from Pelangi's Instagram posts followed by a very detailed description on how she went into labor a year prior. Such posts have been viewed and liked by thousands of followers. The photo and video collages represented Pelangi gratefulness for having Rumi in her life, her adoration of her daughter each day after she was born. Parents, unsurprisingly, share their children incessantly on social media. Pelangi is not an exception. However, considering her profession and status as a social media celebrity, she deliberately curated each picture, video and story that she put on each of her platforms. Reminiscing the actual past posts when she had just delivered Rumi, a year ago, it was clear that the birth story of Rumi was meticulously planned, executed and posted with intent. The authenticity and rawness were captured perfectly by an experienced photographer and birth-specialist videographer who were mentioned and thanked at the end of the post.

While Senft equated the cam-girls phenomenon as theatrically authentic (Senft, 2008), author would prefer to use the term manufactured or staged authenticity by the use of 'professionals' behind such personal experience. It offers some degree of openness in comparison to other celebrities who choose not to share their birthing experiences; however, it is also being manufactured in a sense of the inclusion of professional workers to deliver such 'authentic' moments. Dian Pelangi navigated her private and public on camera, constantly delving into the ordinary everyday life of a woman, but also a glitz and glamour, very wealthy 'not-so-ordinary' Instagram mega-star with revenue reportedly more than one billion Rupiahs per month.

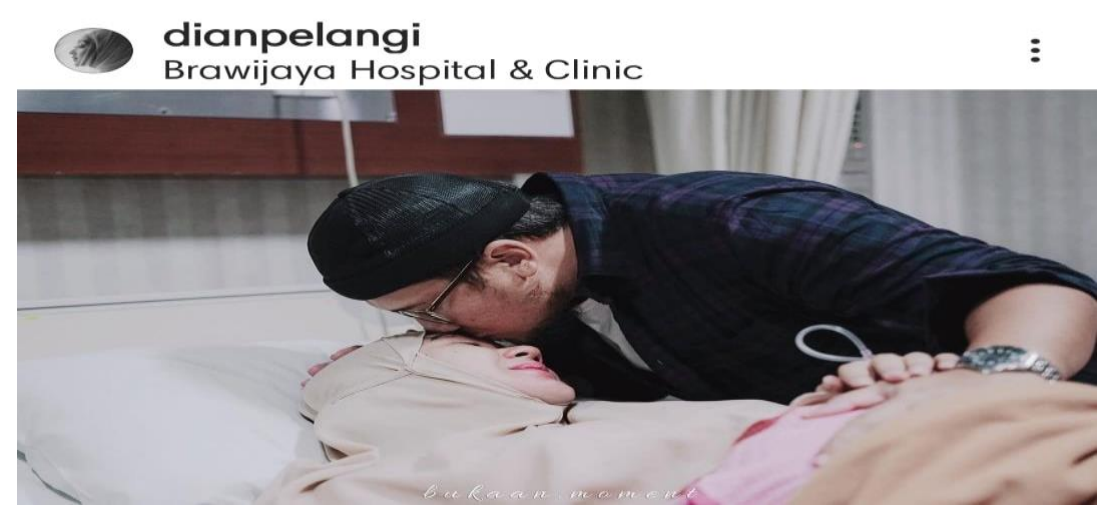

Figure 1. Pelangi’s Instagram post on August 17, 2020

(source: instagram.com/dianpelangi/)

Comparing both posts from Pelangi and Muhammad, the sense of ordinariness was also prevalent in Muhammad's IG feeds. In one of his posts on January 3, 2020, Muhammad showed his son, Baim, eating solid food from the hand of his mother. The portrayal of Muhammad's son is quite rare amongst his other posts, mostly about travelling and holidays across Indonesia and the world, while being supported by many advertisers. Such post generated thousands of comments, since Muhammad showed his 'parenting' side. 


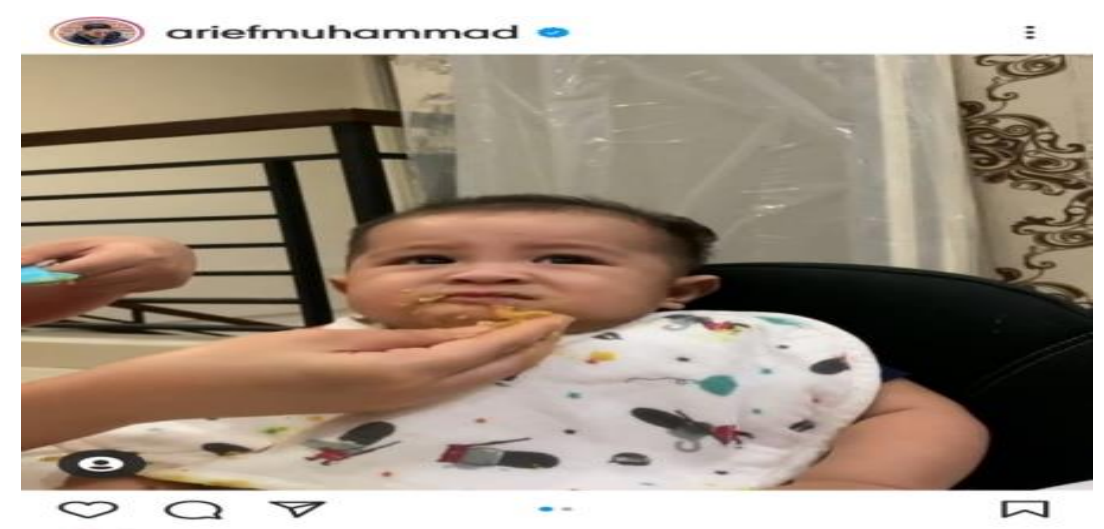

Figure 2. Muhammad's Instagram post on January 3, 2020

(source: instagram.com/ariefmuhammad/)

In comparison to his other posts, the Baim post showed Muhammad's ordinary life, as a proud father of a baby. Scrolling through the comments, his followers commented how such a post reminded them of their own children. Scholars have been addressing such notion by which celebrities play 'ordinary' and 'authenticity' in order to manage their parasocial relationship with their fans (Chung \& Cho, 2014; Schmid \& Klimmt, 2011). In order to be seen as humanely possible apart from their wealth and possessions, parasocial strategy is often being asserted to manage adoration and closeness amongst the fans. Further discussion and reflection will be given in the next section on this paper.

\section{Discussion}

This section looks at the way the micro-celebrities build their online personae by navigating two pertinent factors, authenticity and ordinariness, as manifested through their posts. Some posts that have been generated for the purpose of this research have been taken from the Instagram accounts of both Dian Pelangi and Arief Muhammad, as discussed in the last section. Each picture from both Instagram accounts are analyzed while simultaneously such language towards the written texts following the visual images are also taken into consideration. Distinctive commentaries from their followers are generated to overlook the discursive construction of Instagram's visuals and texts. Within the plethora of visually striking images in their posts, two imperative discourses are inherently dominant, which is the way authenticity and ordinariness are constructed.

Quoting a TV interview by Jennifer Ringley who became one of Senft's research participants on the rise of cam girls in the late 1990s, the 'realness' in the forms of confessional diaries is one factor that made cam girls a phenomenal micro-celebrity case at their peak (Senft, 2008). She also argued that webcams ooze authenticity and humanness that is far more believable than conventional celebrities, whom Ringley described as having 'perfect hair, perfect friends and perfect lives.' Senft later also described Ringley herself as the epitome of beauty by Western standards with their tall, young and slender bodies. Senft concluded that such authenticity is theatrical authenticity, to compare the practice of webcam girls that utilize the advancement of technology such as computer screen, camera and microphone to those of theatrical shows. She also compared the realness and authenticity of webcams to reality television, which is usually more 'contrived' and 'scripted' (Senft, 2008). The rise of micro-celebrities in many social media and networking platforms seems to follow the same logic, that the sense of authenticity and realness become the fundamental aspect of its rise and continuity. The 
same sense of realness and authenticity are also prevalent in both Dian Pelangi and Arief Muhammad's Instagram accounts.

Birth and delivery stories are usually seen as private matters, and most people choose not to share such personal experience online. However, social networking sites have changed this through the number of women who have opted to share their birth stories online, especially through YouTube (Baraitser, 2017; Das, 2018). Although seemingly natural and authentic, posting home-birth videos through YouTube should be seen as self-efficacy in the age of digital neoliberalism (Baraitser, 2017). At first, YouTube and other online platforms were often thought of as spaces of citizenship, where ordinary people can offer their ways of seeing and doing things, in a way mainstream media couldn't fathom. However, although, online digital media such as YouTube has potential to challenge the dominant narrative of motherhood (often in parenting and glossy magazines where motherhood and birthing events are overtly glamorized), Senft's research on numerous home-birth videos on YouTube negates this.

More often, such YouTube birthing videos construct women in their familial and domestic setting and also represent births as glamorous events, celebratory moments with staged home-birth videos by professionals. The potentiality of digital media as spaces of resistance for the 'other' voices of motherhood has been deflected by the rise of neoliberal motherhood which has centered around the promotional aspect of selves which is still in line with the dominant narrative of motherhood (Das, 2018). Dian Pelangi's posts are entertaining and warm, for sure. However her subject position as a micro-celebrity in the digital age whose identity centers around consumerism and digital entrepreneurship does not offer an alternative view of womanhood and motherhood. Pelangi's authentic stories on her labor process are staged and meticulously crafted through the eyes of a professional videographer and photographer. This paper thus concludes that authenticity in Dian Pelangi's account is being made into the glamorous image of motherhood within 60 seconds of Instagram images or a photo snap of her birthing moments along with the many celebrations of her children's birthdays. There are almost no real and raw moments of Pelangi as a mother, which could potentially be an authentic look into the way motherhood is supposedly portrayed. Pelangi's Instagram page is almost as glossy as any parenting and women's magazines, brought and presented by her assembled social media team. The other carefully crafted images of authenticity also work alongside the narrative of ordinariness. This also deeply occurs within Pelangi's Instagram account, as the next section details.

Arief Muhammad's Instagram feed is similar in comparison to Pelangi's. There is nothing ordinary with Muhammad's life. His online meteoric fame derived first from his funny and well-liked Twitter account (@Poconggg). After being anonymous through his Twitter account, he finally revealed his identity and made a lucrative business across social network platforms such as Instagram and YouTube. He married another social media influencer, Tiara Pangestika (Tipang), in 2017 and together they managed various online and offline businesses. As has been said earlier, there is nothing ordinary in Muhammad's Instagram posts. These are filled on a daily basis with beautiful, strikingly manufactured and professionally edited travel photography of where Arief and Tiara have been. They also often posted two different travel destinations in under a week, suggesting the rich and young couple travelling abroad almost every week. Arief has cultivated a successful digital entrepreneurship, that many vloggers and bloggers dream of. 
Hence, within the plethora of images of travel and holidays which filled his Instagram posts, he also constructs some sense of ordinariness. Biressi and Nun suggested that the popularity of reality television is derived from the way the already famous or nonfamous person is being constructed doing ordinary things (Biressi \& Nunn, 2008a). The rise of various reality television formats such as docudrama, competition driven reality shows, such as Big Brother or Dancing with the Stars, changes the way talent and education as the prominent factors of being a celebrity are viewed. Biressi and Nunn asserted that the new 'generation' of reality stars cultivates fame, wealth and prominence without having acquired specific talents from their educational background, business endeavors or any other talent, but merely and solely through reality TV (Biressi \& Nunn, 2005, 2008a; Nunn \& Biressi, 2003). Sometimes reality TV stars have acquired fame and wealth through scandals and controversy, for example, Paris Hilton and Kim Kardashian who, coming from well-off families, gained much attention by recording their sexual activities.

The same assertion which perfectly captures the term micro-celebrity could be applied into the meteoric rise of Arief Muhammad. Just like the way Dian Pelangi depicts her authenticity, Muhammad also offers his followers a glimpse of his life which, though extraordinary with his globetrotting holidays, still offers a degree of being an ordinary man, as a husband and a father. It is difficult to find his posts that are not some form of a publicity endorsement. Almost every one of Muhammad's Instagram posts is a paid product placement, from e-commerce platforms to mobile phones to home utensils and luxurious cars. However, within the plethora of product placement, Arief has smartly crafted his personal experience into such endorsements. For example, one of his Instagram video posts in the past was about a surprise party for his wife where he gave her a diamond jeweler set. While also mentioning the jewelry shop by the end of his post, Muhammad gave a heartfelt backstory that he is now rich enough to buy his wife a set of jewelry. It was his promise since he could not afford to provide such luxury product for her on their wedding day and his mother-in-law lent him some jewelry to avoid embarrassment in front of his extended family. His deeply personal story following the product endorsement cemented the idea of an ordinary hardworking man who had finally achieved his dream to provide for his family. Such posts have been liked and commented on by thousands of his followers, mostly praising him for being such a good husband.

Other posts also showed his 'ordinary' problems, such as Muhammad and his wife doing their weekly grocery shopping or looking for a housemaid to work in their home, as well as several representations of their son on his IG's feeds. Arief Muhammad and his wife did not hesitate to post their difficulties in finding a housemaid through Instagram posts in the hope of information being provided by their followers in finding the right one. While a housemaid is often seen as an expensive worker, typical middle-class Indonesian families employ part-time or full-time housemaids to help with the domestic chores. Thus, for typically middle-class Indonesians, looking for housemaids is often being seen as 'ordinary' problems, especially for working mothers. Arief Muhammad and Tiara Pangestika were no exception. Muhammad is one of the most successful digital entrepreneurs in Indonesia and yet his posts convey the message that somehow he is ordinary. His narrative is carefully constructed to portray him as the face of every digital entrepreneur's dream, that is an ordinary man who achieves financial success through digital labor. While posting his luxury holiday destinations, Muhammad also portrays the 
ordinary side of his lives, such as past financial hardship and domestic issues like looking for the right housemaid and, of course, the challenge of being a new father.

\section{Conclusion}

This paper demonstrates the way micro-celebrity works in the age of social networking sites by investigating what kind of discourses are prevalent in Dian Pelangi and Arief Muhammad's accounts and how Instagram facilitates such discourses. It follows closely the work of Theresa Senft who coined the term micro-celebrity to encapsulates the rise of online fame by ordinary people who have the ability to have emphatic communication skills online (Senft, 2008). This term is extended to look at the way micro-celebrities work, with Instagram being the case study. Two Indonesian microcelebrities, Dian pelangi and Arief Muhammad's Instagram accounts are investigated using multimodal discourse analysis. Discourses of authenticity and ordinariness mostly prevail in both Pelangi and Muhammad's Instagrams. Pelangi and Muhammad's rise to fame through online platforms such as Instagram confirmed the digital myth that the Internet is a place of meritocracy where everyone can be successful without acknowledging the structural inequality toward those who lack in access or knowledge in achieving the same level of success. This paper facilitated such discussion by which discourse around the notion of what is authentic and ordinary was subjected to careful orchestration, selection and meticulous planning in the social media age. Being celebrities in the age of Instagram is no longer a discussion about talents in traditional motion pictures or screen performances, but the business of being a seemingly normal person and yet selling a fantasy of fame, beautiful family and being popular. Despite this elaboration, certain limitations are also illustrated in that this research uses a limited sample. Nevertheless, this paper intends to inspire other research with the subject of Indonesian social media influencers.

\section{Conflict of Interest}

We certify that there is no conflict of interest with any financial, personal, or other relationships with other people or organization related to the material discussed in the manuscript.

\section{Acknowledgements}

The author would like to thank the Communication Science Department, Universitas Pembangunan Nasional "Veteran" Jawa Timur, to whom this research is highly indebted to.

\section{References}

Baraitser, L. (2017). YouTube Birth and the Primal Scene. Performance Research, 22(4), 7-17. https://doi.org/10.1080/13528165.2017.1374661

Berryman, R., \& Kavka, M. (2017). I Guess A Lot of People See Meas a Big Sister or a Friend: the role of intimacy in the celebrification of beauty vloggers. Journal of Gender Studies, 26(3), 307-320. https://doi.org/10.1080/09589236.2017.1288611

Biressi, A., \& Nunn, H. (2005). Reality TV: Realism and Revelation (1st ed.). Columbia University Press.

Biressi, A., \& Nunn, H. (2008a). Class and contemporary british culture. Palgrave Macmillan. 
Biressi, A., \& Nunn, H. (2008b). The especially remarkable: celebrity and social mobility in Reality TV. In A. Biressi \& H. Nunn (Eds.), The Tabloid Culture Reader (1st ed.). Open University Press.

Borges-Rey, E. (2015). News Images on Instagram. Digital Journalism, 3(4), 571-593. https://doi.org/10.1080/21670811.2015.1034526

Burke, T. J., \& Ruppel, E. K. (2014). Facebook Self-Presentational Motives: Daily Effects on Social Anxiety and Interaction Success. Communication Studies, 66(2), 204-217. https://doi.org/10.1080/10510974.2014.884014

Caldeira, S. P. (2020). "Shop it. Wear it. 'Gram it.": a qualitative textual analysis of women's glossy fashion magazines and their intertextual relationship with Instagram. Feminist Media Studies, 20(1), 86-103. https://doi.org/10.1080/14680777.2018.1548498

Choi, G. Y., \& Lewallen, J. (2017). Say Instagram, Kids!: Examining Sharenting and Children's Digital Representations on Instagram. Howard Journal of Communications, $29(2)$, https://doi.org/10.1080/10646175.2017.1327380

Chung, S., \& Cho, H. (2014). Parasocial relationship via reality TV and social media: its implications for celebrity endorsement. In Ink.library.smu.edu.sg. http://ink.library.smu.edu.sg/cgi/viewcontent.cgi?article=5329\&context=lkcsb_res earch

Click, M. A., Lee, H., \& Holladay, H. W. (2013). Making Monsters: Lady Gaga, Fan Identification, and Social Media. Popular Music and Society, 36(3), 360-379. https://doi.org/10.1080/03007766.2013.798546

Das, R. (2018). Mediated subjectivities of the maternal: A critique of childbirth videos on YouTube. The Communication Review, 21(1), 66-84. https://doi.org/10.1080/10714421.2017.1416807

Djafarova, E., \& Trofimenko, O. (2018). Instafamous: credibility and self-presentation of micro-celebrities on social media. Information, Communication \& Society, 1-15. https://doi.org/10.1080/1369118x.2018.1438491

Evans, N. J., Phua, J., Lim, J., \& Jun, H. (2017). Disclosing Instagram Influencer Advertising: The Effects of Disclosure Language on Advertising Recognition, Attitudes, and Behavioral Intent. Journal of Interactive Advertising, 17(2), 138149. https://doi.org/10.1080/15252019.2017.1366885

Fitrianti, A., Febriana, K. A., \& Ersyad, F. A. (2020). Personal Branding Cino Fajrin through Instagram. Jurnal The Messenger, 12(1), 74-83. http://dx.doi.org/10.26623/themessenger.v12i1.1641

Francis, D. B., Stevens, E. M., Noar, S. M., \& Widman, L. (2018). Public Reactions to and Impact of Celebrity Health Announcements: Understanding the Charlie Sheen Effect. Howard Journal of Communications, 30(5), 479-494. https://doi.org/10.1080/10646175.2018.1532852

Franssen, G. (2019). Sincerity and authenticity in celebrity culture: introduction. Celebrity Studies, 10(3), 315-319. https://doi.org/10.1080/19392397.2019.1630117

Ghaffari, S. (2020). Discourses of celebrities on Instagram: digital femininity, selfrepresentation and hate speech. Critical Discourse Studies, O(0), 1-18. https://doi.org/10.1080/17405904.2020.1839923

Giles, D. C. (2002). Parasocial Interaction: A Review of the Literature and a Model for 
Future Research. Media Psychology, 4(3), 279-305. https://doi.org/10.1207/s1532785xmep0403_04

Giles, D. C. (2017). How do fan and celebrity identities become established on Twitter? A study of social media natives and their followers. Celebrity Studies, 8(3), 445460. https://doi.org/10.1080/19392397.2017.1305911

Haastrup, H. K. (2020). The mother of dragons in Dior: fashion, star image and selfpresentation on Instagram. Popular Communication, 18(4), 327-340. https://doi.org/10.1080/15405702.2020.1839078

Hall-Patton, C. R. (2014). Celebrification of a pawn star. Celebrity Studies, 5(4), 379393. https://doi.org/10.1080/19392397.2014.916624

Hall, S. (1999). Encoding, Decoding. In S. During (Ed.), The cultural studies reader (1st ed.). Sage publications, Inc.

Ingleton, P., \& York, L. (2019). From Clooney to Kardashian: reluctant celebrity and social media. Celebrity Studies, 10(3), 364-379. https://doi.org/10.1080/19392397.2019.1630152

Jerslev, A. (2019). A real show for mature women ageing along with ageing stars: Grace and Frankie fandom on Facebook. In Taylor \& Francis. https://doi.org/10.1080/19392397.2018.1465298

Kalika, A., \& Ferrucci, P. (2019). Examining TMZ: What traditional digital journalism can learn from celebrity news. Communication Studies, 70(2), 172-189. https://doi.org/10.1080/10510974.2018.1562949

Kaymas, S., \& Yakin, O. (2019). Bodies in alliance: rethinking cultural and economic logics of social media celebrity constitution in Turkey's new media ecosystem. Celebrity Studies, 1-16. https://doi.org/10.1080/19392397.2019.1587306

Khamis, S., Ang, L., \& Welling, R. (2016). Self-branding, micro-celebrity and the rise of Social Media Influencers. Celebrity Studies, 8(2), 191-208. https://doi.org/10.1080/19392397.2016.1218292

Lau, S. (2010). stylebubble.com:This website is for sale! stylebubble Resources and Information. In Stylebubble.com. http://stylebubble.com

Lee, S., \& Kim, E. (2020). Influencer marketing on Instagram: How sponsorship disclosure, influencer credibility, and brand credibility impact the effectiveness of Instagram promotional post. Journal of Global Fashion Marketing, 11(3), 232-249. https://doi.org/10.1080/20932685.2020.1752766

Machin, D., \& Mayr, A. (2012). How To Critical Discourse Analysis (1st ed.). SAGE Publication.

MacIsaac, S., Kelly, J., \& Gray, S. (2017). She has like 4000 followers!: the celebrification of self within school social networks. Journal of Youth Studies, 21(6), 816-835. https://doi.org/10.1080/13676261.2017.1420764

Marshall, P. D. (2010). The promotion and presentation of the self: celebrity as marker of presentational media. Celebrity Studies, 1(1), 35-48. https://doi.org/10.1080/19392390903519057

Marshall, P. D., Moore, C., \& Barbour, K. (2015). Persona as method: exploring celebrity and the public self through persona studies. Celebrity Studies, 6(3), 288-305. https://doi.org/10.1080/19392397.2015.1062649

Mohamad, S. M., \& Hassim, N. (2019). Hijabi celebrification and Hijab consumption in Brunei and Malaysia. Celebrity Studies, 1-25. https://doi.org/10.1080/19392397.2019.1677164 
Nunn, H., \& Biressi, A. (2003). Silent witness: detection, femininity, and the post-mortem body. Feminist Media Studies, 3(2), 193-206. https://doi.org/10.1080/1468077032000119317

Octaviana, O. (2016). Gambaran Branding Esgrim House Semarang Melalui Media Sosial. Jurnal The Messenger, 8(1), 51-56. http://dx.doi.org/10.26623/themessenger.v8i1.314

Pan, P.-L., \& Zeng, L. (2017). Parasocial Interactions with Basketball Athletes of Color in Online Mediated Sports. Howard Journal of Communications, 29(2), 196-215. https://doi.org/10.1080/10646175.2017.1354790

Rahmawati, A. (2009). The Social Meaning of Hijab: Hijab in Indonesian Islamic Magazines. Airlangga University.

Rahmawati, A. (2018). Romance and Femininities in Indonesian Teenage Dramas: A Transnational Post-Feminist Analysis. In http://indonesianfeministjournal.org. http://indonesianfeministjournal.org/index.php/IFJ/article/view/216

Rahmawati, A. (2019). Romance and Femininities in Indonesian Teenage Dramas: A Transnational Post-Feminist Analysis. In http://indonesianfeministjournal.org. http://indonesianfeministjournal.org/index.php/IFJ/article/view/216

Rahmawati, A., \& Febriyanti, S. (2012). Cultural Studies: Analisis Kuasa atas kebudayaan. In Eprints.upnjatim.ac.id. http://eprints.upnjatim.ac.id/3177/1/2_Cultural_Studies_Analisis_Kuasa_Atas_Ke budayaan_-_Aulia_R_dan_Syafrida_NF.pdf

Schmid, H., \& Klimmt, C. (2011). A magically nice guy: Parasocial relationships with Harry Potter across different cultures. International Communication Gazette, 73(3), 252-269. https://doi.org/10.1177/1748048510393658

Senft, T. M. (2008). Camgirls. Lang.

Zulli, D. (2017). Capitalizing on the look: insights into the glance, attention economy, and Instagram. Critical Studies in Media Communication, 35(2), 137-150. https://doi.org/10.1080/15295036.2017.1394582 